\title{
Experimental and Theoretical Investigations of Heat Generation Rates for a Water Cooled $\mathrm{LiFePO}_{4}$ Battery
}

\author{
S. Panchal ${ }^{1 *}$, I. Dincer ${ }^{1}$, M. Agelin-Chaab ${ }^{1}$, R. Fraser ${ }^{2}$, and M. Fowler ${ }^{3}$ \\ ${ }^{1}$ Department of Automotive, Mechanical \& Manufacturing Engineering, Faculty of Engineering \& Applied Science, \\ University of Ontario Institute of technology, 2000 Simcoe Street North, Oshawa, Ontario, Canada, L1H 7K4 \\ ${ }^{2}$ Mechanical and Mechatronic Engineering Department, University of Waterloo, 200 University Avenue West, \\ Waterloo, Ontario, Canada, N2L 3G1 \\ ${ }^{3}$ Chemical Engineering Departments, University of Waterloo, 200 University Avenue West, Waterloo, Ontario, \\ Canada, N2L 3G1 \\ *Corresponding Author's Telephone: +1-519-722-4420, \\ *Corresponding Author’s Email: satyam.panchal@uoit.ca, satyam.panchal@uwaterloo.ca
}

\begin{abstract}
Understanding the rate of heat generation in a lithium-ion cell is critical for the safety and performance behaviour. This paper presents in situ measurements of the heat generation rate for a prismatic Lithiumion battery at $1 \mathrm{C}, 2 \mathrm{C}, 3 \mathrm{C}$ and $4 \mathrm{C}$ discharge rates and $5^{\circ} \mathrm{C}, 15^{\circ} \mathrm{C}, 25^{\circ} \mathrm{C}$, and $35^{\circ} \mathrm{C}$ boundary conditions (BCs). For this work, an aluminum-laminated battery consisting of $\mathrm{LiFePO}_{4}$ cathode material with $20 \mathrm{Ah}$ capacity was adopted to investigate the variation of the rate of heat generation as a function of the discharge capacity. Ten thermocouples and three heat flux sensors were applied to the battery surface at distributed locations. The results of this study show that the highest rate of heat generation was found to be $91 \mathrm{~W}$ for $4 \mathrm{C}$ discharge rate and $5{ }^{\circ} \mathrm{C} \mathrm{BC}$ while the minimum value was $13 \mathrm{~W}$ measured at $1 \mathrm{C}$ discharge rate and $35{ }^{\circ} \mathrm{C}$ BC. It was also found that the increase in discharge rate and thus the discharge current caused consistent increase in the heat generation rate for equal depth of discharge points. The model is later developed using the neural network approach and validated. The heat generation rate predicted by the simulation demonstrates an identical behavior with experimental results.
\end{abstract}

Keywords: Lithium-ion battery, Heat transfer, Heat generation rate, Thermal management.

\section{Introduction}

Nowadays, the energy crisis is a key issue due to limited fossil fuels sources and concerns over greenhouse emissions [1,2]. Today, the lithium-ion battery is considered as a suitable energy storage device for alternative energy sources, such as wind and solar, and has many advantages: i) high specific energy and power densities [3, 4]; ii) high nominal voltage and low self-discharge rate [5] ; and iii) long cycle-life and no memory effect [6]. That is why; the lithium-ion battery is the most advanced battery 
technology for electric vehicles (EVs), hybrid electric vehicles (HEVs), and plug-in hybrid electric vehicles (PHEVs). Small consumer products such as laptops, cell phones, toys, radios, laser pointers, slide changers, and many other consumer products also use lithium-ion batteries as the main or secondary power source [7]. However, disadvantageous properties, such as thermal behavior at high discharging rates still remain; therefore, it is crucial to obtain accurate knowledge of battery heat generation and a thermal management system in EV applications [8,9]. Lithium-ion polymer batteries must be carefully monitored and managed (electrically and thermally) to avoid safety (inflammability) and performance related issues $[10,11,12]$.

A lithium-ion battery cells usually has five different layers, namely: the negative current collector, negative electrode (anode), separator, positive electrode (cathode), and positive current collector. The positive electrode materials [13,14] are typically four types: 1) a metal oxide with a layered structure, such as lithium cobalt oxide $\left(\mathrm{LiCoO}_{2} / \mathrm{LCO}\right)$ [15]; 2) a metal with a three dimensional spinal structure, such as lithium manganese oxide $\left(\mathrm{LiMn}_{2} \mathrm{O}_{4}\right)$ [16]; 3) lithium nickel manganese cobalt oxide ( $\mathrm{LiNiMnCoO}_{2} / \mathrm{NMC}$ ); and 4) a metal with an olivine structure, such as lithium iron phosphate $\left(\mathrm{LiFePO}_{4} / \mathrm{LFP}\right)$ [17]. The anode is usually made of graphite or a metal oxide. The electrolyte can be liquid, polymer or solid.

At a high temperature environment, lithium ion batteries degrade rapidly, while in a cold temperature environment, the power output and energy are reduced which ultimately results in reduction of performance and driving range [18]. Power fade, capacity fade and self-discharge are well known performance related problems at high temperatures [19]. In addition, safety at high temperatures is a major concern [20]. Therefore, an efficient battery thermal management system (BTMS) is required that uses an optimal thermal design, which relies on a good understanding of the heat generation within the batteries. There are two basic types of cooling systems: 1) air cooling, and 2) water cooling. The advantage of air cooling is electrical safety but it has lower heat transfer coefficient, which makes it more difficult to obtain a uniform temperature distributions. On the other hand, water cooling is more effective and occupies less volume, but has high complexities as well as high cost and weight [21].

Now, to understand the thermal behavior of batteries and its impact on battery performance and life, the first step experimentally is to study the battery temperature distributions and the heat generation profiles at different charge and discharge rates. To make this study relevant to EVs, HEVs, and PHEVs, the charge and discharge rates must be typical of those seen and expected to be seen in vehicles. Figure 1 shows the surface temperature of a lithium-ion pouch cell at different discharge rates of $\mathrm{C} / 5, \mathrm{C} / 2,1 \mathrm{C}, 2 \mathrm{C}$, 3C and 4C (C-rate is the measurement of the charge and discharge current of a battery), on the order of 
those seen in vehicles. The charge rate between discharges in all cases is $1 \mathrm{C}$. Figure 1 illustrates the thermal spikes that can accompany discharge. Over a short 20 minute time period (short from a vehicle operation viewpoint) for $3 \mathrm{C}$ and a 15 minute time period for $4 \mathrm{C}$ discharge, enough heat is generated to increase the cell temperature to $46^{\circ} \mathrm{C}$ (for $3 \mathrm{C}$ ) and $58^{\circ} \mathrm{C}$ (for $4 \mathrm{C}$ ) from a $22^{\circ} \mathrm{C}$ start condition. This value is only for a single pouch cell with a free convection boundary condition, thus an even greater temperature can result when extrapolated to approximately 300 pouch cells in a battery pack of PHEVs, HEVs, and EVs, where there is no free boundary convection, but only conduction between pouch cells. This problem is explained below.

Operating lithium-ion batteries above $50^{\circ} \mathrm{C}$ can accelerate the aging process and lead to significant degradation of battery capacity and electric range reduction. Following from Figure 1, battery cell temperatures above $50^{\circ} \mathrm{C}$ are very possible, especially when cells are stacked into modules, and then packs, and if the ambient temperature is closer to $50^{\circ} \mathrm{C}$ than the $22^{\circ} \mathrm{C}$ used in Figure 1 . The possibility of fire is also a major issue with high operating temperatures where thermal runaway is a possibility. Furthermore, even if thermal runaway does not occur, significant degradation of battery capacity can result by consistently operating at elevated temperature $\left(>50^{\circ} \mathrm{C}\right)[22]$. Thus, adequate battery cooling and thermal management are an integral part of the vehicle operation during electric mode operation. EVs, HEVs, and PHEVs require a robust battery thermal management system in order to ensure optimal (safe, good performance, and long battery life) vehicle operation.

Various researchers have studied the thermal characteristics by combining the numerical simulation technology and experiment method. There are numerous papers available in the open literature for battery thermal modeling, using different approaches, such as an artificial neural network [23, 24], finite element model (FEM) [25, 26] or lumped parameter model (LPM) [27], linear parameter varying (LPV) model [28], partial differential equation (PDE) model [29] or equivalent circuit model (ECM) [30, 31]. Thermal parameters can be determined using analytical relations which need a previous knowledge of the battery $[25,30]$. They can also be experimentally determined by adapting a model to experimental data [32]. Here, for the battery modeling, we used a neural network approach. Neural networks are usually organized in layers with nodes or neurons connecting different layers through an activation function. The data or pattern is presented at the input layer which travels to the hidden layers through weighted connections and is finally processed at the output layer which represents the output of the network [23, 24].

In this paper, the research conducted on the investigation of the variation of the rate of heat generation as a function of the discharge capacity for a particular lithium-ion battery under different discharge rates 
$(1 \mathrm{C}, 2 \mathrm{C}, 3 \mathrm{C}$ and $4 \mathrm{C})$ and various boundary conditions $(\mathrm{BCs})$ of $5^{\circ} \mathrm{C}, 15^{\circ} \mathrm{C}, 25^{\circ} \mathrm{C}$, and $35^{\circ} \mathrm{C}$ is presented. First, an experimental study will be presented and the simulated results on the heat generation rate of the lithium-ion battery using a neural network model will then be discussed.

\section{Experimental Set-up}

The schematic of the experimental set-up is shown in Figure 2. Computer-1 provides the basic controls using LabVIEW VI to the controller and load box via RS-232 cables and the power supply with an Ethernet cable. The computer also offers a GUI for the user to monitor the progress of the experiment. The controller uses analog I/O signal wiring to communicate with the relays and measure the battery voltage. The controller transmits the measured battery voltage back to computer-1, which sets the current or voltage values on the load box and power supply, depending on the experiment. The current, measured internally by the load box and power supply, is transmitted back to computer-1. Depending on the computer requests, the power supply or load box will provide power to or draw power from the battery, respectively. Computer-2 provides the thermal data via the Keithley data acquisition system. Regarding temperature measurements in the experiments, there were ten T-type thermocouples installed on the principal surface of the battery. In addition to this, three heat flux sensors (one near the anode, the second near the cathode, and the third, near the mid body) were mounted on the another surface of the battery. Further details on the experimental setup and procedure are provided in some earlier publications elsewhere [23, 24, 33].

The battery used for this work and cold plate set-up with battery is shown in Figure 3a and 3b. A commercially available cold plate is used for this experimental work in order to remove the heat generated from the lithium-ion battery during discharge. The plate is characterized as having a single flow channel with one inlet and one outlet placed on both the top and bottom of the battery. The single flow channel runs down the length of the plate before turning back on itself, stepping one channel width across the plate with each turn. This flow pattern results in a thermal profile where the coolant temperature gradient is largest across the width of the plate. A Microtherm FS1 30-300 $\mathrm{ml} / \mathrm{min}$ flow meter was installed directly upstream of the inlet to each cooling plate. An LCD display provides instantaneous measurement of volumetric flow. This volumetric flow value was manually recorded at the beginning and end of test cycles. The flow rate of water to the upper cold plate was $150 \mathrm{~mL} / \mathrm{min}$, and the flow rate of water to the lower cold plate was $150 \mathrm{~mL} / \mathrm{min}$. A Lithium-ion battery is insulated from three sides to prevent heat loss from the battery to the surrounding. A 20 Ah lithium-ion prismatic pouch cell was used for the test measurements and subsequent model validation. The basic parameters of a LFP battery cell can be seen in Table 1. All measurements were performed using a Keithley 2700 data acquisition system. 
A 20 channel M7700 analog input module was used to connect to the output terminals of all the instruments. The Keithley 2700 data logger and M7700 input module is shown in Figure 4.

\section{Analysis and Model Development}

There are two main sources for the heat generation in a battery: first, Joule's heating or Ohmic heating and second, the entropy change due to electrochemical reactions $[34,35,36]$. The heat can be endothermic for charging and exothermic for discharge based on the electrode pair. The heat generation in a battery is defined as follows:

$$
\dot{Q}=I\left(E-V_{a}\right)-I\left[T\left(\frac{d E}{d T}\right)\right]
$$

where $I\left(E-V_{a}\right)$ is known as the Ohmic or Joule's heating and $I[T(d E / d T)]$ is known as the reversible heat resulting from changes in open circuit voltage with respect to temperature at two electrodes. Usually, the second term is small compared to the first term and therefore negligible for the EV and HEV current rates [37]. There are relatively few studies which report experimental measurements of heat generation, especially in situ measurements. It is clearly desirable to develop real-time measurement methods for high C-rate processes that can be implemented in realistic conditions. Here, in this research, the total heat generation rate from a battery was calculated by using the following equation:

$$
\dot{Q}_{t o t}=\dot{Q}_{b}+\dot{Q}_{c p}+\dot{Q}_{e}
$$

where, $\dot{Q}_{b}$ is the rate of heat stored in the battery (also known as sensible heat) and given by

$$
\dot{Q}_{b}=m_{b} c_{p, b} \frac{d T}{d t}
$$

$\dot{Q}_{c p}$ is the cooling plate heat removal rate, determined by the inlet and outlet thermocouple data, in conjunction with the recorded flow rates and calculated for a single cold plate as follows:

$$
\dot{Q}_{C P}=\dot{m}_{w} C_{p, w}\left(T_{w, o}-T_{w, i}\right)
$$

Here, the total heat removed by the cooling plates (upper and bottom cold plates) for $\Delta t$ time period is calculated by

$$
Q_{C p}=\dot{m}_{w} C_{p, w}\left(T_{w, o, a v g}-T_{w, i, a v g}\right) \Delta t
$$

Note that the term $T_{w, o, a v g}$ is the average measured outlet temperature during the period $\Delta \mathrm{t}$, as in equation (6). $\mathrm{N}_{\mathrm{T}}$ represents the number of temperature readings in the summation. 


$$
T_{w, o, a v g}=\frac{\sum T_{w, o}}{N_{T}}
$$

In equation (2), $\dot{Q}_{e}$ is the rate of heat from the environment. An environment heat was incorporated because the battery and cold plate set-up was not perfectly insulated, due to which heat gain or loss from the environment occurs. When cooling (e.g., $\left.5^{\circ} \mathrm{C}\right)$ is below ambient temperature $\left(22^{\circ} \mathrm{C}\right)$, a temperature difference of $17{ }^{\circ} \mathrm{C}$ occurs, which results in heat transfer from ambient air to the cooling fluid. This additional heat is taken as an increased temperature difference between the inlets and outlets. The opposite mechanism occurs when the cooling (e.g., $\left.35^{\circ} \mathrm{C}\right)$ is set above ambient temperature $\left(22{ }^{\circ} \mathrm{C}\right)$. For the natural air convection, the total heat generation was also calculated and the methodology and results are discussed in detail in a previous paper [38]. In order to evaluate this effect, the cooling system and Keithley 2700 data acquisition system was activated along with the lithium-ion battery in place between two cold plates but during this operation where there was no charging or discharging of the battery. In this way, the temperature difference between the inlet and outlet of each cooling plate can be recorded. The average difference for each plate along with the respective flow rates used were used to quantify the heat removed or added by the environment using the method presented in above section of cold plates. The heat removed or added by the environment for different coolant temperature is shown in Figure 5.

The battery thermal model is developed for the rate of heat generation using the neural network approach based upon the data acquired from the thermal boundary condition test apparatus using dual cold plates for a 20Ah lithium-ion battery. The neural network architecture for the battery model is shown in Figure 6. There are three inputs to the model and the selected numbers of hidden neurons are fourteen. For training the model, we used the Levenberg-Marquardt Method which, due to its robust nature, is the default training algorithm for the feed-forward network in many commercial solvers including MATLAB. This algorithm takes more memory, but less time. It automatically trains when generalization stops improving, as indicated by an increase in the mean square error (MSE) of the validation samples. The model was trained a few times until the MSE was minimum and regression value $(R)$ was close to one, which implies there is a close relationship between targets and outputs.

There are basically three inputs to the model. The first is boundary condition or ambient temperature. The external temperature has a great effect on the battery performance. Therefore, to increase the accuracy of the modeling, the BCs or ambient temperature have been considered over the same time period and granularity as in the output. The second input is the discharge current. This is basically the discharge rate for the battery that is being discharged at a constant current. The discharge rates are $1 \mathrm{C}, 2 \mathrm{C}, 3 \mathrm{C}$ and $4 \mathrm{C}$. The third input is the battery capacity. The battery discharge capacity is measured over the entire time 
period. This is typically measured with the discharge current multiplied by the time in hours over the entire discharge of the battery for the above mentioned discharge rates. The capacity is the time integral of the current, calculated by equation (7).

$$
\text { Capacity }=A h=\int_{0}^{t}(I) d t
$$

In the output file, there is one output for the heat generation rate. The heat generation rate of the battery is simulated based on the target. The data is measured with a sampling period of one second over a time horizon of 24 hours. There were total 12923 samples (with all discharge rates (1C, 2C, 3C and 4C) and all boundary conditions $\left(5^{\circ} \mathrm{C}, 15^{\circ} \mathrm{C}, 25^{\circ} \mathrm{C}\right.$, and $\left.35^{\circ} \mathrm{C}\right)$ ) considered for this model, out of which, $70 \%$ samples (9045) were used for training the model. Also, 15\% of the samples (i.e., 1937) were used for validation, and hence these were used for testing the model. A histogram showing the difference between the actual and the target output is shown in Figure 7. Among the total samples considered, the majority of errors lie in the range of -2.2 to 3.6. This range represents the frequency of the errors for the number of sample. It is also noted that the majority of errors are occurring with probability of 0.96 .

\section{Results and Discussion}

\subsection{Heat Generation Rate Uncertainty}

Here in this paper, we used a very well-known method called Moffat method in [39] to obtain the uncertainty analysis of the experimental results and theoretical predictions. In this method, the R of an experiment is determined by equation (8) from a set of measurements $\mathrm{M}$

$$
R=R\left(X_{1}, X_{2}, X_{3}, \ldots, X_{N}\right)
$$

Each measurement can be represented as $\mathrm{X}_{\mathrm{i}} \pm \delta \mathrm{X}_{\mathrm{i}}$ where $\delta \mathrm{X}_{\mathrm{i}}$ is the uncertainty. The effect of each measurement error on the calculated result is determined by equation (9).

$$
\delta \mathrm{R}_{\mathrm{X}_{\mathrm{i}}}=\frac{\delta \mathrm{R}}{\delta \mathrm{X}_{\mathrm{i}}} \delta \mathrm{X}_{\mathrm{i}}
$$

Hence, the overall uncertainty of the result is determined using equation (10).

$$
\delta \mathrm{R}=\left\{\sum_{\mathrm{i}=1}^{\mathrm{N}}\left(\frac{\delta \mathrm{R}}{\delta \mathrm{X}_{\mathrm{i}}} \delta \mathrm{X}_{\mathrm{i}}\right)^{2}\right\}^{1 / 2}
$$

If $R$ is described by an equation of the form $R=X_{1}^{a} X_{2}^{b} X_{3}^{c} \cdots \cdots X_{N}^{m}$ then the overall uncertainty of the result can be determined directly from the set of individual measurement uncertainties and is given by equation (11). 


$$
\frac{\delta \mathrm{R}}{\mathrm{R}}=\left\{\left(\mathrm{a} \frac{\delta \mathrm{X}_{1}}{\mathrm{X}_{1}}\right)^{2}+\left(\mathrm{b} \frac{\delta \mathrm{X}_{2}}{\mathrm{X}_{1}}\right)^{2}+\cdots \cdots \cdots \cdot\left(\mathrm{m} \frac{\delta \mathrm{X}_{\mathrm{N}}}{\mathrm{X}_{1}}\right)^{2}\right\}^{1 / 2}
$$

The uncertainty in total heat generated is made up of the uncertainties of the components that calculate the heat. It is calculated via

$$
\frac{\delta Q_{t o t}}{Q_{t o t}}= \pm\left\{\left(\frac{\delta Q_{b}}{Q_{b}}\right)^{2}+\left(\frac{\delta Q_{c p}}{Q_{c p}}\right)^{2}+\left(\frac{\delta Q_{e}}{Q_{e}}\right)^{2}\right\}^{1 / 2}
$$

The uncertainty in the rate of total heat generation is calculated by

$$
\frac{\delta \dot{Q}_{t o t}}{\dot{Q}_{t o t}}= \pm\left\{\left(\frac{\delta \dot{Q}_{b}}{\dot{Q}_{b}}\right)^{2}+\left(\frac{\delta \dot{Q}_{c p}}{\dot{Q}_{c p}}\right)^{2}+\left(\frac{\delta \dot{Q}_{e}}{\dot{Q}_{e}}\right)^{2}\right\}^{1 / 2}
$$

The sensible heat calculation is based on the mass of the battery, battery specific heat capacity and average surface temperature. The battery mass and specific heat capacity were reported by the manufacturer and assumed to have no uncertainty. Thus the uncertainty in sensible heat is as shown in equation (14).

$$
\frac{\delta Q_{b}}{Q_{b}}= \pm \frac{\delta \Delta T_{s, a v g}}{\Delta T_{s, a v g}}
$$

The uncertainty in the rate of sensible heat accumulation is calculated using equation (15).

$$
\frac{\delta \dot{Q}_{b}}{\dot{Q}_{b}}= \pm\left\{\left(\frac{\delta \Delta T_{s, a v g}}{\Delta T_{s, a v g}}\right)^{2}+\left(\frac{\delta \Delta \mathrm{t}_{D c h g}}{\Delta \mathrm{t}_{D c h g}}\right)^{2}\right\}^{1 / 2}
$$

The relative uncertainty in surface temperature difference is largest when the temperature difference is smallest. Equation (16) was used to calculate the uncertainty in average surface temperature differences.

$$
\frac{\delta \Delta T_{s, a v g}}{\Delta T_{s, a v g}}= \pm\left\{\left(\frac{\delta T_{s, a v g}}{T_{s, a v g}}\right)^{2}+\left(\frac{\delta T_{s, a v g}}{T_{s, a v g}}\right)^{2}\right\}^{1 / 2}
$$

Discharge time was calculated based on the output from the Labview controlled charge/discharge bench. The uncertainty is taken to be equal to the resolution of the time measurement, and is therefore taken to be 1 second. The largest uncertainty occurs during the shortest discharge and is determined using equation (17). The largest uncertainty will be carried through to simplify further calculations.

$$
\frac{\delta \Delta \mathrm{t}_{D c h g}}{\Delta \mathrm{t}_{D c h g}}= \pm \frac{1 \sec }{\Delta \mathrm{t}_{D c h g}}
$$


The cooling heat energy calculation is based on the mass flow rate of the cooling fluid, the coolant specific heat capacity and temperature difference of the coolant between the inlet and outlet of the cooling plates. The uncertainty in the coolant flow rate is assumed to be negligible and the uncertainty in the cooling heat energy is calculated using equation (18).

$$
\frac{\delta Q_{c p}}{Q_{c p}}= \pm\left\{\left(\frac{\delta \dot{m}}{\dot{m}}\right)^{2}+\left(\frac{\delta \Delta T}{\Delta T}\right)^{2}+\left(\frac{\delta \Delta \mathrm{t}_{D c h g}}{\Delta \mathrm{t}_{D c h g}}\right)^{2}\right\}^{1 / 2}
$$

The uncertainty in the rate of sensible heat accumulation is calculated using equation (19).

$$
\frac{\delta \dot{Q}_{c p}}{\dot{Q}_{c p}}= \pm\left\{\left(\frac{\delta \dot{m}}{\dot{m}}\right)^{2}+\left(\frac{\delta \Delta T_{w}}{\Delta T_{w}}\right)^{2}\right\}^{1 / 2}
$$

The volumetric flow rate of the cooling fluid was measured with Microtherm FS1 30-300 mL/min flow meters. Specifications provided by the manufacturer list instrument uncertainty at $6 \%$ of full scale error, which is $\pm 18 \mathrm{~mL} / \mathrm{min}$. This uncertainty is equivalent to equation (20). The highest relative uncertainty will be carried through to simplify further calculations.

$$
\frac{\delta \dot{m}}{\dot{m}}= \pm \frac{18 \mathrm{~mL} / \mathrm{min}}{\dot{m}[\mathrm{~mL} / \mathrm{min}]}
$$

The uncertainty associated with the temperature difference between the inlet and outlet of the cooling plates is determined by

$$
\frac{\delta \Delta T_{w}}{\Delta T_{w}}= \pm\left\{\left(\frac{1{ }^{\circ} \mathrm{C}}{T_{w, i}\left[{ }^{\circ} \mathrm{C}\right]}\right)^{2}+\left(\frac{1{ }^{\circ} \mathrm{C}}{T_{w, o}\left[{ }^{\circ} \mathrm{C}\right]}\right)^{2}\right\}^{1 / 2}
$$

The method of determining the environment heat effect is equivalent to the method used to find the heat removed by the cooling plate. As such, the uncertainty associated with environmental heat gain is equivalent to the uncertainty in heat removed by the cooling plates. A summary of the uncertainties for the volumetric flow rate, temperature between the inlet and outlet of the cooling plates, average surface temperature, cooling plate heat removal, cooling plate heat removal rate, environmental heat, environmental heat rate, the heat stored in the battery, the rate of heat stored in the battery, total heat generation and total rate of heat generation is tabulated in Table 2.

\subsection{Heat Generation Rate Validation}

Figure 8 and Figure 9 show comparisons of the actual and simulated rates of heat generation as a function of discharge capacity (Ah) at $1 \mathrm{C}, 2 \mathrm{C}, 3 \mathrm{C}$ and $4 \mathrm{C}$ discharge rates at $5{ }^{\circ} \mathrm{C}$ and $15{ }^{\circ} \mathrm{C} \mathrm{BC}$. Similarly, Figure 
10 and Figure 11 show a comparison of the actual and simulated rate of heat generation at $1 \mathrm{C}, 2 \mathrm{C}, 3 \mathrm{C}$ and $4 \mathrm{C}$ discharge rates at $25{ }^{\circ} \mathrm{C}$ and $35^{\circ} \mathrm{C} \mathrm{BCs}$. At the lower discharge rate of $1 \mathrm{C}$, the rate of heat generation remains approximately constant from the beginning to almost $80 \%$ of the discharge. Overall, the simulated data agrees well with the experimental data which demonstrates the robustness and accuracy of the model. However, there is still a small degree of discrepancy between the simulated and experimental data in the fine structure occurring at the early periods of the discharge process, appearing most evident for $3 \mathrm{C}$ and $4 \mathrm{C}$. A steep rise in the rate of heat generation at the beginning of the discharge (1 Ah) was also observed, at which point the heat generation rate tends to reach a steady state approximately until $60 \%$ of the discharge rate when a steady increase is observed. The increase in the heat generation rate becomes steeper as the discharge progresses and the highest near the end of discharge.

It was also found that the highest rate of heat generation was $91 \mathrm{~W}$ measured at $4 \mathrm{C}$ discharge rate and $5^{\circ} \mathrm{C}$ $\mathrm{BC}$ and the minimum value was $13 \mathrm{~W}$ measured at $1 \mathrm{C}$ discharge rate and $35{ }^{\circ} \mathrm{C} \mathrm{BC}$. The trend observed is that increased discharge rates (between 1C, 2C, 3C, and 4C) and decreased operating temperature (between $35{ }^{\circ} \mathrm{C}, 25{ }^{\circ} \mathrm{C}, 15^{\circ} \mathrm{C}$, and $5{ }^{\circ} \mathrm{C}$ ), results in increased rate of heat generation. The variations in the BCs from $5^{\circ} \mathrm{C}$ to $35^{\circ} \mathrm{C}$ and increase in C-rates also have a great effect on the discharge capacity. It was found that as the $\mathrm{C}$-rate increased the discharge capacity (Ah) of the battery decreases and the discharge capacity increases when the $\mathrm{BCs}$ increase from $5^{\circ} \mathrm{C}$ to $35^{\circ} \mathrm{C}$. In general, increased C-rates and decreased BCs result in decreased discharge capacity.

\section{Conclusions}

In this paper, a model for the rate of heat generation on a prismatic lithium-ion battery at $1 \mathrm{C}, 2 \mathrm{C}, 3 \mathrm{C}$ and $4 \mathrm{C}$ discharge rates and different $\mathrm{BCs}$ of $5^{\circ} \mathrm{C}, 15^{\circ} \mathrm{C}, 25^{\circ} \mathrm{C}$ and $35^{\circ} \mathrm{C}$ using the dual cold plate approach with the indirect liquid cooling method was developed. The model is validated through the comparison of experimental results and proves to be in strong agreement. The developed model successfully captured the discharge behaviour over a wide range of $\mathrm{C}$-rates and $\mathrm{BCs}$. The maximum values of heat generation rates are also obtained from the experimental data analysis. The influences of the cold plates on the battery heat generation rate were also studied. The following concluding remarks can be stated. 1) The rate of heat generation increased as the discharge rates increased from $1 \mathrm{C}$ to $4 \mathrm{C}$; 2) The highest heat generation rate was noted for $4 \mathrm{C}$ discharge rate and $5{ }^{\circ} \mathrm{C} \mathrm{BC}$; 3) The minimum value of the rate of heat generation was measured at $1 \mathrm{C}$ discharge rate and $35^{\circ} \mathrm{C} \mathrm{BC}$; and 4) The variations in the $\mathrm{BCs}$ from $5^{\circ} \mathrm{C}$ to $35^{\circ} \mathrm{C}$ and increase in $\mathrm{C}$-rates have a great effect on the discharge capacity. 


\section{Nomenclature}

$$
\begin{array}{ll}
E & =\text { open circuit voltage }[\mathrm{V}] \\
C_{p} & =\text { specific heat capacity }\left[\mathrm{J} / \mathrm{kg}^{\circ} \mathrm{C}\right] \\
\frac{d E}{d T} & =\text { temperature coefficient }\left[\mathrm{V} /{ }^{\circ} \mathrm{C}\right] \\
I & =\text { current }[\mathrm{A}] \\
m & =\text { mass }[\mathrm{kg}] \\
\dot{m} & =\text { mass flow rate }[\mathrm{kg} / \mathrm{s}] \\
\mathrm{ml} / \mathrm{min} & =\text { flow rate in milliliter per minute } \\
\mathrm{N}_{\mathrm{T}} & =\text { number of temperature readings in the summation } \\
Q & =\text { heat generation }[\mathrm{J}] \\
\dot{Q} & =\text { rate of heat generation }[\mathrm{W}] \\
T & =\text { temperature }\left[{ }^{\circ} \mathrm{C} \text { or } \mathrm{K}\right] \\
t & =\text { time }[\mathrm{s}] \\
V & =\text { cell voltage or cell potential }[\mathrm{V}]
\end{array}
$$

\section{Subscripts}

$$
\begin{array}{ll}
a & =\text { actual } \\
a v g & =\text { average } \\
b & =\text { battery } \\
c p & =\text { cold plate } \\
\text { Dchg } & =\text { discharge } \\
e & =\text { environment } \\
\text { sim } & =\text { simulated } \\
s & =\text { surface } \\
\text { tot } & =\text { total } \\
w, o & =\text { outlet water } \\
w, i & =\text { inlet water } \\
w & =\text { water }
\end{array}
$$

\section{Acronyms}

A

$\mathrm{Ah}$

$\mathrm{BC}$

BTMS
Ampere

Ampere-hour

Boundary condition

Battery thermal management system 


\begin{tabular}{|c|c|}
\hline $\mathrm{C}$ & Discharge rate \\
\hline EV & Electric vehicle \\
\hline ECM & Equivalent circuit model \\
\hline FEM & Finite element model \\
\hline $\mathrm{HEV}$ & Hybrid electric vehicle \\
\hline GUI & Graphical user interface \\
\hline $\mathrm{I} / \mathrm{O}$ & Input/output \\
\hline LabVIEW & Laboratory virtual instrument engineering workbench \\
\hline $\mathrm{LiCoO}_{2}$ & Lithium cobalt oxide \\
\hline $\mathrm{LiMn}_{2} \mathrm{O}_{4}$ & Lithium manganese oxide \\
\hline $\mathrm{LiNiMnCoO}_{2}$ & Lithium manganese cobalt oxide \\
\hline $\mathrm{LiFePO}_{4}$ & Lithium iron phosphate \\
\hline LCO & Lithium cobalt oxide \\
\hline LFP & Lithium phosphate \\
\hline LPM & Lumped parameter model \\
\hline LPV & Linear parameter varying \\
\hline MSE & Mean square error \\
\hline MATLAB & Matrix Laboratory \\
\hline NMC & Lithium manganese cobalt oxide \\
\hline PDE & Partial differential equation \\
\hline PHEV & Plug-In hybrid electric vehicle \\
\hline RS-232 & Recommend standard number 232 \\
\hline
\end{tabular}

\section{References}

[1] A. Babapoor, M. Azizi and G. Karimi, "Thermal management of a Li-ion battery using carbon fiberPCM," Applied Thermal Engineering, vol. 82, pp. 281-290, 2015.

[2] Y. Lai, S. Du, L. Ai, A. Lihua, Y. Cheng, Y. Tang and J. Ming, "Insight into heat generation of lithium ion batteries based on the electrochemical-thermal model at high discharge rates," International Journal of Hydrogen Energy, vol. 40, pp. 3039-3049, 2015.

[3] Z. Ling, F. Wang, X. Fang, X. Gao and Z. Zhang, "A hybrid thermal management system for lithium ion batteries combining phase change materials with forced-air cooling," Applied Energy, no. 148, pp. 403-409, 2015.

[4] Z. G. Qu, W. Q. Li and W. Q. Tao, "Numerical model of the passive thermal management system for high-power lithium ion battery by using porous metal foam saturated with phase change material," International Journal of Hydrogen Energy, vol. 39, no. 8, pp. 3904-3913, 2014.

[5] A. Ritchie and W. Howard, "Recent developments and likely advances in lithium-ion batteries," 
Journal of Power Sources, vol. 162, pp. 809-812, 2006.

[6] Y. Ye, L. H. Saw, Y. Shi and A. A. Tay, "Numerical analyses on optimizing a heat pipe thermal management system for lithium-ion batteries during fast charging," Applied Thermal Engineering, vol. 86, pp. 281-291, 2015.

[7] R. Abousleiman, A. Al-Refai and O. Rawashdeh, "Charge capacity versus charge time in CC-CV and pulse charging of Li-ion batteries," in SAE International, 2013.

[8] J. Marcicki and X. G. Yang, "Model-Based Estimation of Reversible Heat Generation in Lithium-Ion Cells," Journal of Electrochemical Society, vol. 161, pp. A1794-A1800, 2014.

[9] S. J. Andreasen, L. Ashworth, S. Sahlin, H.-C. B. Jensen and S. K. Kær, "Test of hybrid power system for electrical vehicles using a lithium-ion battery pack and a reformed methanol fuel cell range extender," International Journal of Hydrogen Energy, vol. 39, no. 4, pp. 1856-1863, 2014.

[10] Y. Xing, Q. Miao, K.-L. Tsui and M. Pecht, "Prognostics and health monitoring for lithium-ion battery," in IEEE International Conference on, 2011.

[11] X. Feng, M. Fang, X. He, M. Ouyang, L. Lu, H. Wang and M. Zhang, "Thermal runaway features of large format prismatic lithium ion battery using extended volume accelerating rate calorimetry," Journal of Power Sources, pp. 255 : 294-301, 2014.

[12] L. Lu, X. Han, J. Hua, M. Ouyang and J. Li, "A review on the key issues for lithium-ion battery management in electric vehicles," Journal of Power Sources, pp. 226:272-288, 2013.

[13] K. Yeow, M. Thelliez, H. Teng and E. Tan, "Thermal Analysis of a Li-ion Battery System with Indirect Liquid Cooling Using Finite Element Analysis Approach," SAE International Journal, vol. 1, no. 1, pp. 65-78, 2012.

[14] A. Dinger, R. Martin, X. Mosquet, M. Rabl, D. Rizoulis and G. Sticher, "Batteries for Electric Cars,Challenges, Opportunities, and the Outlook to 2020," The Boston Consulting Group, 2010.

[15] L. Y. Shao-Horn, C. Delmas, C. E. Nelson and M. A. O'Keefe, "Atomic resolution of lithium ions in LiCoO2," Nature Materials, vol. 2, pp. 464-467, 2003.

[16] C. Julien, "Local Structure of lithiated manganese oxides," Solid State Ionics, vol. 177, pp. 11-19, 2006.

[17] J. T. Bloking, S. Y. Chung and Y. M. Chiang, "Electrically conductive phospho-olivines as lithium storage electrodes," Nature Materials, vol. 1, pp. 123-128, 2002.

[18] B. Wu, V. Yufit, M. Marinescu, G. J. Offer, R. F. Martinez-Botas and N. P. Brandon, "Coupled thermal-electrochemical modelling of uneven heat generation in lithium-ion battery packs," Journal of Power Sources, vol. 243, pp. 544-554, 2013.

[19] S. J. Drake, M. Martin, D. A. Wetz, J. K. Ostanek, S. P. Miller and A. Jain, "Heat generation rate measurement in a Li-ion cell at large C-rates through temperature and heat flux measurements," Journal of Power Sources, vol. 285, pp. 266-273, 2015.

[20] D. P. Abraham, E. P. Roth, R. Kostecki, K. McCarthy, S. MacLaren and D. H. Doughty, "Diagnostic examination of thermally abused high-power lithium-ion cells," Journal of Power Sources, vol. 161, no. 1, pp. 648-657, 2006.

[21] G.-H. Kim, A. Pesaran and R. Spotnitz, "A three-dimensional thermal abuse model for lithium-ion cells," Journal of Power Sources, vol. 170, no. 2, pp. 476-489, 2007.

[22] P. Ramadass, B. Haran, R. White and B. N. Popov. , "Capacity fade of Sony 18650 cells cycled at elevated temperatures: Part I. Cycling performance," Journal of Power Sources, vol. 112, pp. 606613, 2011.

[23] S. Panchal, I. Dincer, M. Agelin-Chaab, R. Fraser and M. Fowler, "Experimental and theoretical investigation of temperature distributions in a prismatic lithium-ion battery," International Journal of Thermal Sciences, no. 99, pp. 204-212, 2015. 
[24] S. Panchal, I. Dincer, M. Agelin-Chaab, R. Fraser and M. Fowler, "Thermal modeling and validation of temperature distributions in a prismatic lithium-ion battery at different discharge rates and varying boundary conditions," Applied Thermal Engineering, vol. 96, pp. 190-199, 2015.

[25] A. Pruteanu, B. V. Florean, G. Maria Moraru and R. C. Ciobanu, "Development of a thermal simulation and testing model for a superior lithium-ion-polymer battery," in Optimization of Electrical and Electronic Equipment (OPTIM), IEEE, pages 947-952, 2012.

[26] N. Damay, C. Forgez, M.-P. Bichat and G. Friedrich, "Thermal modeling of large prismatic $\mathrm{LiFePO} 4$ /graphite battery.Coupled thermal and heat generation models for characterization and simulation," Journal of Power Sources, vol. 283, pp. 37-45, 2015.

[27] C. Alaoui, "Solid-State Thermal Management for Lithium-Ion EV Batteries," Vehicular Technology, IEEE Transactions on, vol. 62, no. 1, pp. 98-107, 2013.

[28] X. Hu, S. Asgari, S. Lin, S. Stanton and W. Lian, "A linear parameter-varying model for HEV/EV battery thermal modeling," in Energy Conversion Congress and Exposition (ECCE), IEEE, pages 1643-1649, 2012.

[29] A. Smyshlyaev, M. Krstic, N. Chaturvedi, J. Ahmed and A. Kojic, "PDE model for thermal dynamics of a large," in American Control Conference (ACC), IEEE, pages 959-964, 2011.

[30] C. Forgez, D. V. Do, G. Friedrich, M. Morcrette and C. Delacourt, "Thermal modeling of a cylindrical LiFePO4/graphite lithium-ion battery," Journal of Power Sources, vol. 195, no. 9, pp. 2961-2968, 2010.

[31] C. Alaoui, "Solid-State Thermal Management for Lithium-Ion EV Batteries," Vehicular Technology, IEEE Transactions, vol. 62, no. 1, pp. 98-107, 2012.

[32] M. Fleckenstein, S. Fischer, O. Bohlen and B. Bäker, "Thermal Impedance Spectroscopy - A method for the thermal characterization of high power battery cells," Journal of Power Sources, vol. 223, no. 1, pp. 259-267, 2013.

[33] S. Panchal, I. Dincer, M. Agelin-Chaab, R. Fraser and M. Fowler, "Experimental temperature distributions in a prismatic lithium-ion battery at varying conditions," International Communications in Heat and Mass Transfer, vol. 71, pp. 35-43, 2016.

[34] C. R. Pals and J. Newman, "Thermal modeling of the lithium/polymer battery," Journal of the Electrochemical Society, vol. 142, no. 10, pp. 3274-3281, 1995.

[35] Y. Chen and J. W. Evans, "Three-dimensional thermal modeling of lithium-polymer batteries under galvanostatic discharge and dynamic power profile," Journal of the Electrochemical Society, vol. 141, no. 11, pp. 2947-2952, 1994.

[36] G. Wierschem, B. McKinney and E. Nrotek, "Thermal management of lead-acid batteries for electric vehicles," in Research and developement testing, Detroit, 1993.

[37] K. Smith and C.-Y. Wang, "Power and thermal characterization of a lithium-ion battery pack for hybrid-electric vehicles," Journal of Power Sources, vol. 160, no. 1, pp. 662-673, 2006.

[38] S. Panchal, S. Mathewson, R. Fraser, R. Culham and M. Fowler, "Thermal Management of LithiumIon Pouch Cell with Indirect Liquid Cooling using Dual Cold Plates Approach," SAE International, vol. 4, no. 2, 2015.

[39] R. J. Moffat, "Uncertainty analysis," in Electronics Cooling-Dedicated to Thermal Management in Electronic Industry, 1999. 


\section{List of Table Captions}

Table 1: Parameters of $\mathrm{LiFePO}_{4}-20 \mathrm{Ah}$ lithium-ion prismatic battery cell

Table 2: Summary of uncertainty

\section{List of Figure Captions}

Figure 1: Surface temperature profile of a lithium-ion pouch cell during $1 \mathrm{C}$ charge and $1 \mathrm{C}, 2 \mathrm{C}, 3 \mathrm{C}$ and $4 \mathrm{C}$ discharge rates

Figure 2: Schematic of the hybrid test bench

Figure 3: 20Ah LFP battery and cold plate set-up

Figure 4: Keithley 2700 data logger and M7700 input module

Figure 5: Ambient heat flow to compression rig for four coolant temperatures

Figure 6: Neural network architecture

Figure 7: Error histogram

Figure 8: Comparison of actual and simulated heat generation rate at $1 \mathrm{C}, 2 \mathrm{C}, 3 \mathrm{C}$ and $4 \mathrm{C}$ at $5{ }^{\circ} \mathrm{C}$ and 15

${ }^{\circ} \mathrm{C} \mathrm{BCs}$

Figure 9: Comparison of actual and simulated heat generation rate at $1 \mathrm{C}, 2 \mathrm{C}, 3 \mathrm{C}$ and $4 \mathrm{C}$ at $25^{\circ} \mathrm{C}$ and 35 ${ }^{\circ} \mathrm{C} \mathrm{BCs}$

Figure 10: Comparison of actual and simulated heat generation rate at $1 \mathrm{C}, 2 \mathrm{C}, 3 \mathrm{C}$ and $4 \mathrm{C}$ at $25^{\circ} \mathrm{C} \mathrm{BCs}$

Figure 11: Comparison of actual and simulated heat generation rate at $1 \mathrm{C}, 2 \mathrm{C}, 3 \mathrm{C}$ and $4 \mathrm{C}$ at $35^{\circ} \mathrm{C} \mathrm{BCs}$ 


\section{Tables}

Table 1 : Parameters of $\mathrm{LiFePO}_{4}$ - 20Ah lithium-ion prismatic battery cell

\begin{tabular}{|l|l|}
\hline \multicolumn{1}{|c|}{ Specifications } & \multicolumn{1}{c|}{ Value } \\
\hline Cathode Material & $\mathrm{LiFePO}_{4}$ \\
\hline Anode Material & Graphite \\
\hline Electrolyte & Carbonate based \\
\hline Nominal Capacity & $20.0 \mathrm{Ah}$ \\
\hline Nominal Voltage & $3.3 \mathrm{~V}$ \\
\hline Dimensions & $7.25 \mathrm{~mm} \times 160 \mathrm{~mm} \times 227 \mathrm{~mm}$ \\
\hline
\end{tabular}

Table 2 : Summary of uncertainty

\begin{tabular}{|c|c|c|c|}
\hline Variable & Range & Temperature $\left[{ }^{\circ} \mathrm{C}\right]$ & \pm Relative Uncertainty $(\%)$ \\
\hline$\dot{m}[\mathrm{~mL} / \mathrm{min}]$ & $170 \mathrm{~mL} / \mathrm{min}-218 \mathrm{~mL} / \mathrm{min}$ & - & $8.3 \%-10.6 \%$ \\
\hline$\Delta T_{w}\left[{ }^{\circ} \mathrm{C}\right]$ & $0.1^{\circ} \mathrm{C}-2.6^{\circ} \mathrm{C}$ & - & $0 \%-21.9 \%$ \\
\hline$T_{S, \text { avg }}\left[{ }^{\circ} \mathrm{C}\right]$ & $5.6^{\circ} \mathrm{C}-44.5^{\circ} \mathrm{C}$ & - & $0.48 \%-28.5 \%$ \\
\hline$\dot{Q}_{c p}[\mathrm{~W}]$ & $2.91 \mathrm{~W}-50.61 \mathrm{~W}$ & - & $24.4 \%$ \\
\hline$Q_{c p}[\mathrm{~J}]$ & $5992 \mathrm{~J}-11162 \mathrm{~J}$ & - & $24.4 \%$ \\
\hline$\dot{Q}_{e}[\mathrm{~W}]$ & $4.13 \mathrm{~W}-21.60 \mathrm{~W}$ & - & $24.4 \%$ \\
\hline$Q_{e}[\mathrm{~J}]$ & $3382.5 \mathrm{~J}-66991 \mathrm{~J}$ & - & $24.4 \%$ \\
\hline \multirow[t]{4}{*}{$\dot{Q}_{b}[\mathrm{~W}]$} & $0.51 \mathrm{~W}-24.08 \mathrm{~W}$ & 5 & $28.8 \%$ \\
\hline & & 15 & $3.69 \%$ \\
\hline & & 25 & $1.71 \%$ \\
\hline & & 35 & $1.02 \%$ \\
\hline \multirow[t]{4}{*}{$Q_{b}[\mathrm{~J}]$} & $1817 \mathrm{~J}-29554 \mathrm{~J}$ & 5 & $28.7 \%$ \\
\hline & & 15 & $3.68 \%$ \\
\hline & & 22 & $1.56 \%$ \\
\hline & & 25 & $1.70 \%$ \\
\hline \multirow[t]{4}{*}{$\dot{Q}_{t o t}[\mathrm{~W}]$} & $2.321 \mathrm{~W}-58.558 \mathrm{~W}$ & 5 & $44.9 \%$ \\
\hline & & 15 & $34.7 \%$ \\
\hline & & 25 & $34.5 \%$ \\
\hline & & 35 & $34.5 \%$ \\
\hline \multirow[t]{4}{*}{$Q_{t o t}[\mathrm{~J}]$} & $8090 \mathrm{~J}-41345 \mathrm{~J}$ & 5 & $44.9 \%$ \\
\hline & & 15 & $34.7 \%$ \\
\hline & & 22 & $24.4 \%$ \\
\hline & & 25 & $34.5 \%$ \\
\hline
\end{tabular}




\section{Figures}

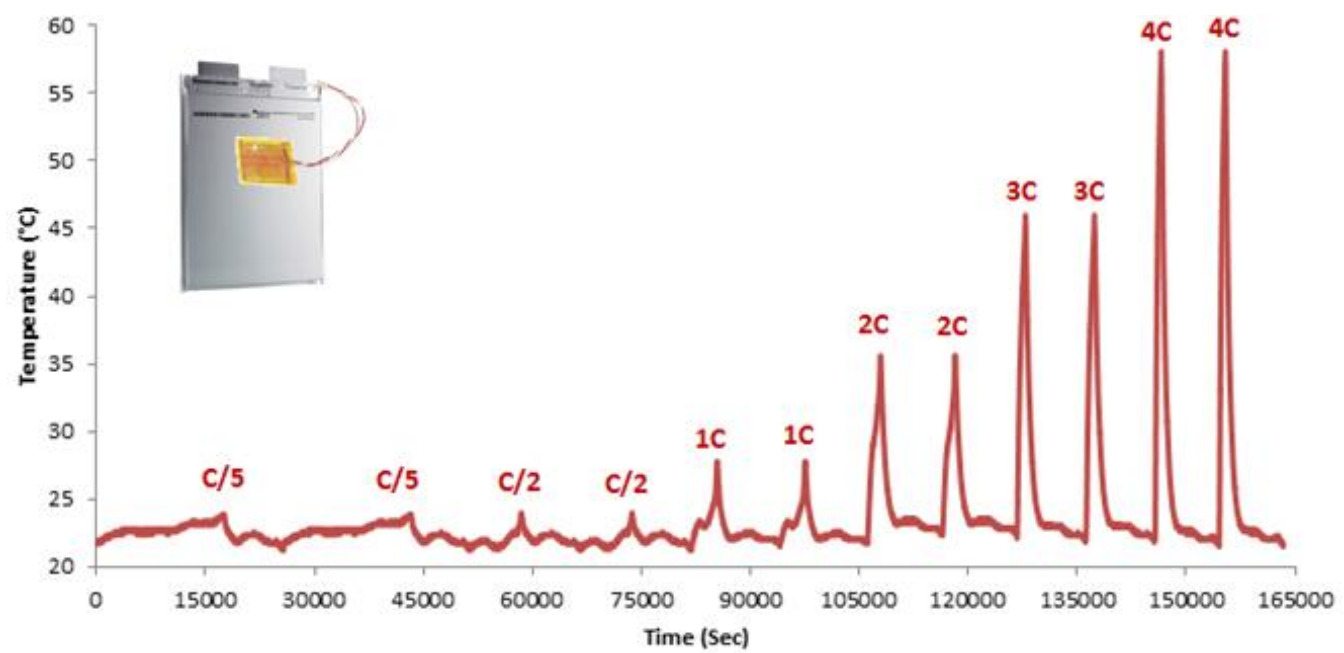

Figure 1 : Surface temperature profile of a lithium-ion pouch cell during $1 \mathrm{C}$ charge and $\mathrm{C} / 5, \mathrm{C} / 2,1 \mathrm{C}, 2 \mathrm{C}, 3 \mathrm{C}$ and $4 \mathrm{C}$ discharge rates

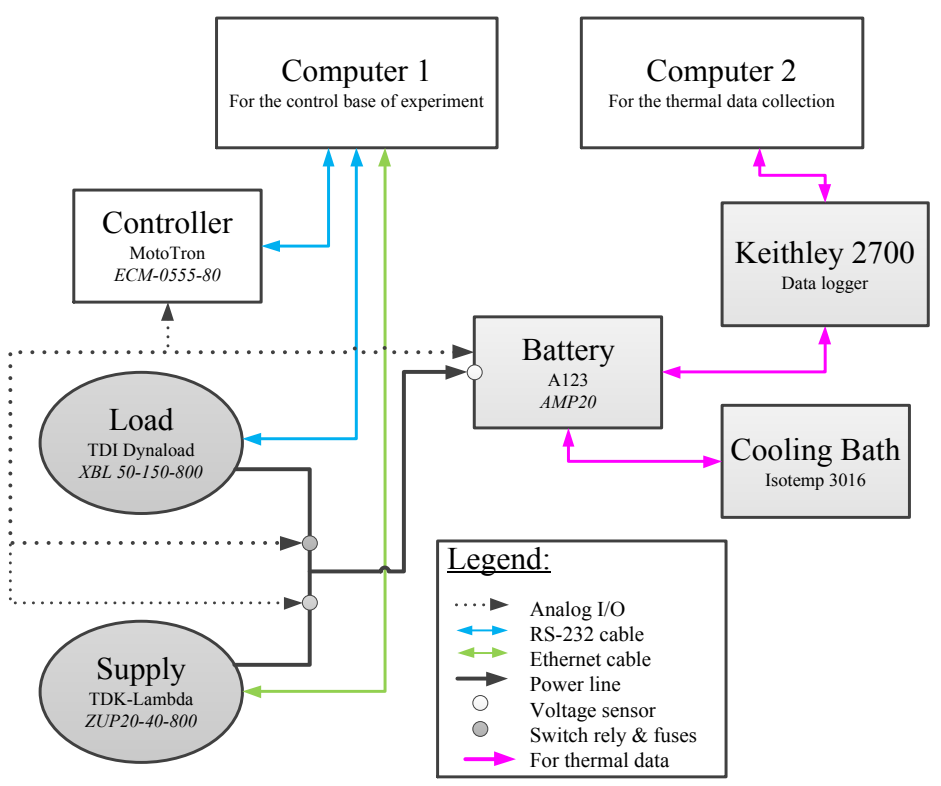

Figure 2 : Schematic of the hybrid test bench 


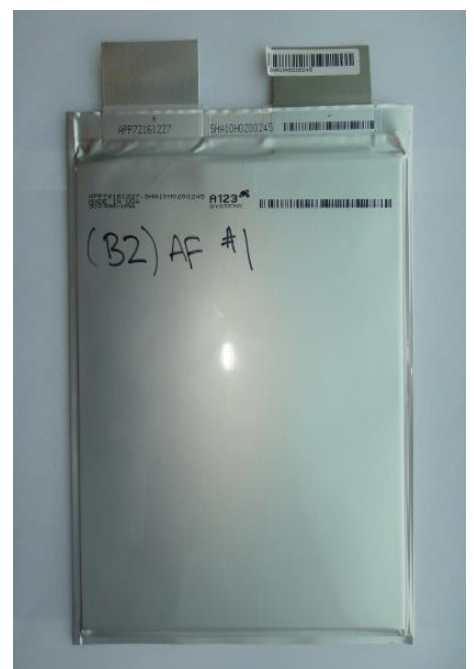

a) $\mathrm{LiFePO}_{4}-20 \mathrm{Ah}$ Battery

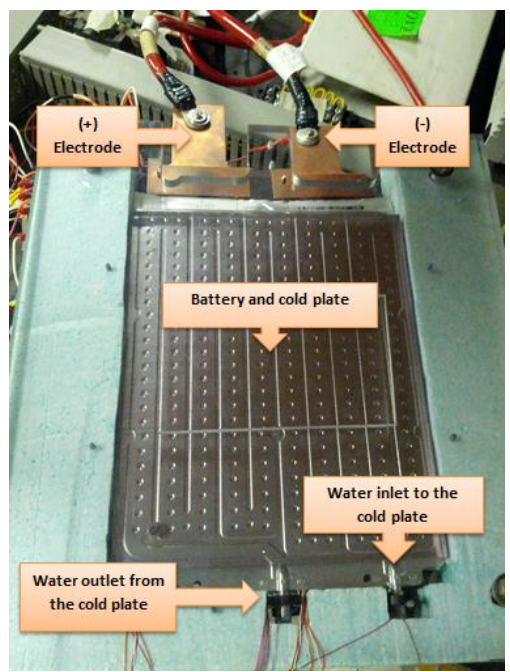

b) Battery and cold plate set-up

Figure 3 : 20Ah LFP Battery and cold plate set-up
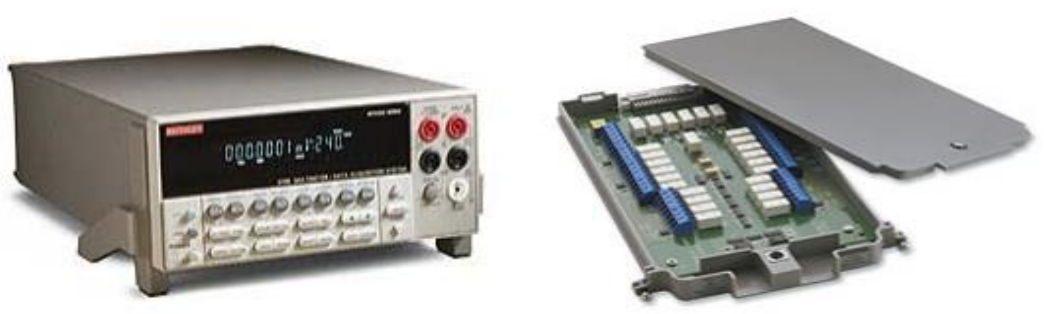

Figure 4 : Keithley 2700 data logger and M7700 input module

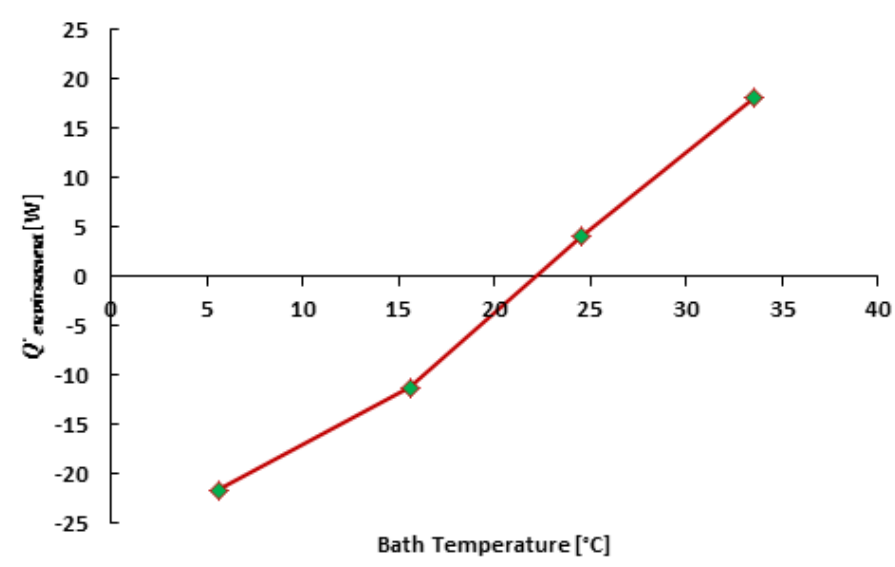

Figure 5 : Ambient heat flow to battery and cold plate set-up for four bath temperatures 


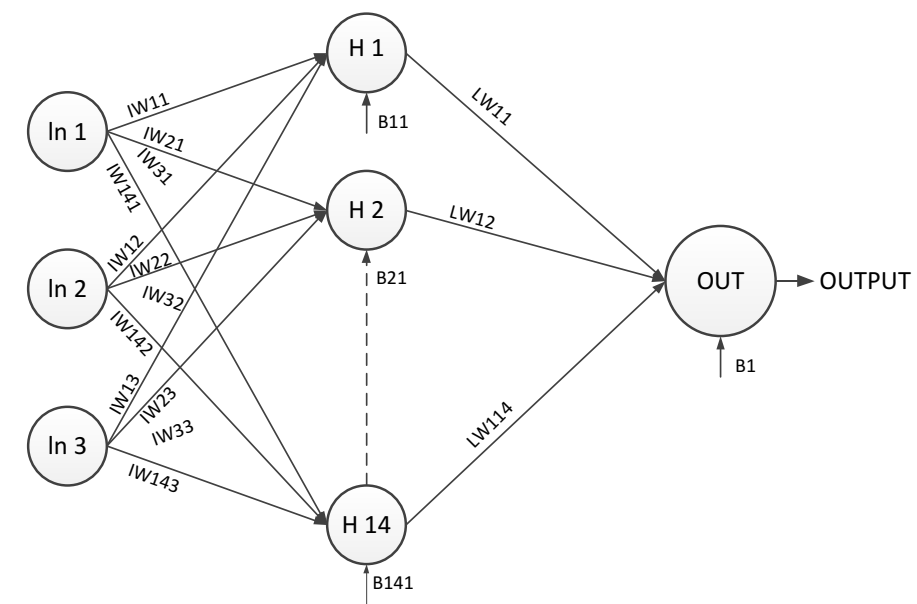

Figure 6 : Architecture of neural network employed

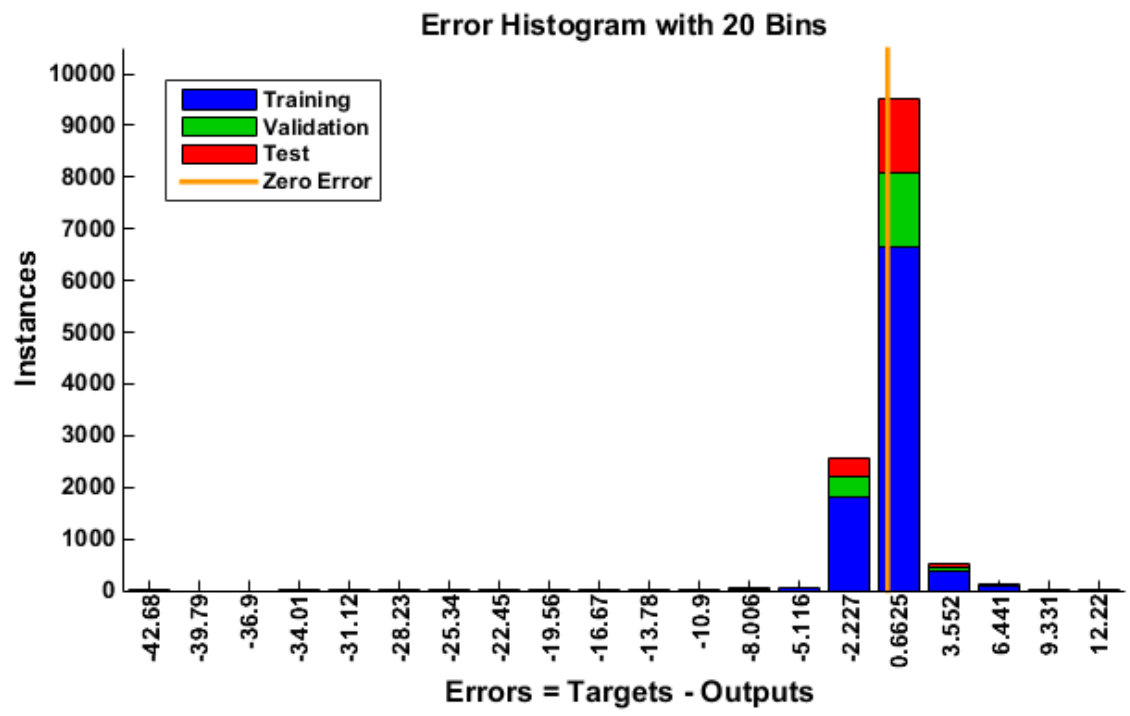

Figure 7 : Error histogram showing the difference between the actual and the target output

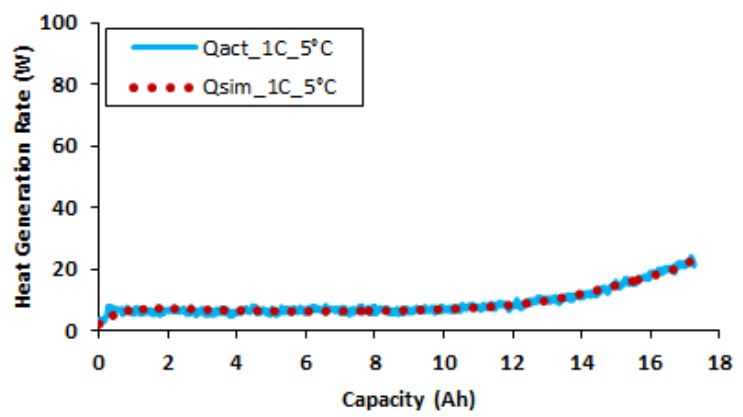

(a) Heat Generation Rate_1C at $5^{\circ} \mathrm{C}$

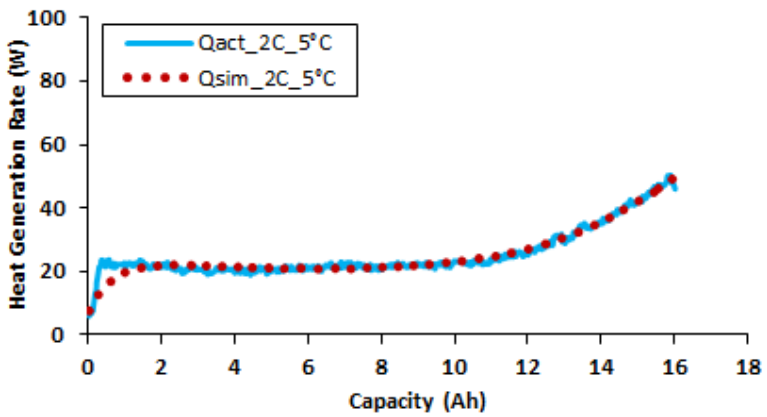

(b) Heat Generation Rate_2C at $5^{\circ} \mathrm{C}$ 


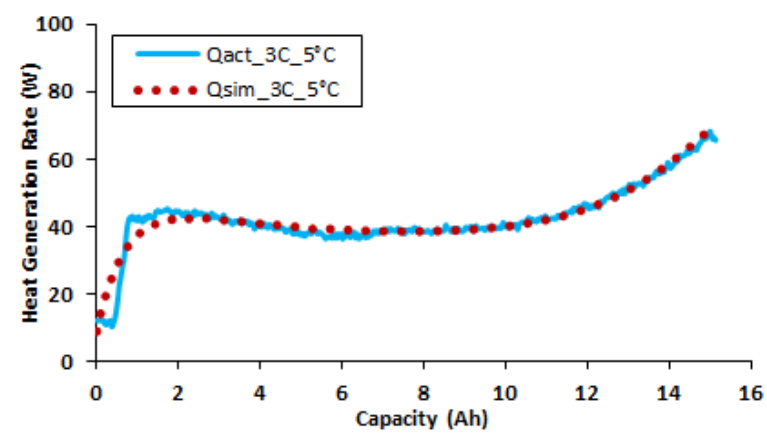

(c) Heat Generation Rate_3C at $5^{\circ} \mathrm{C}$

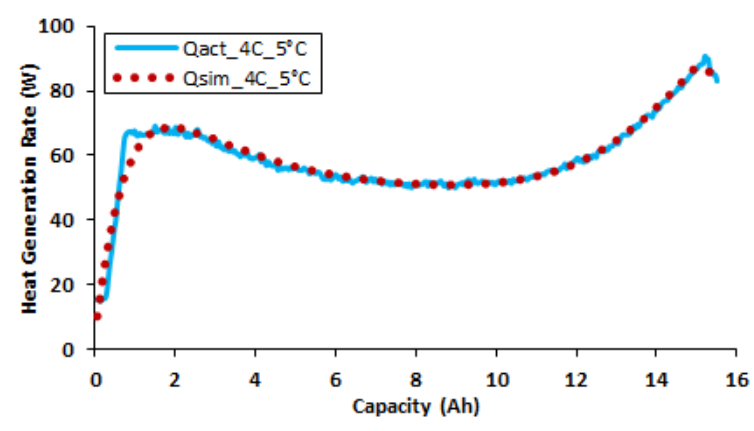

(d) Heat Generation Rate_4C at $5^{\circ} \mathrm{C}$

Figure 8 : Comparison of actual and simulated heat generation rate at $1 \mathrm{C}, 2 \mathrm{C}, 3 \mathrm{C}$ and $4 \mathrm{C}$ at $5{ }^{\circ} \mathrm{C}$ BCs

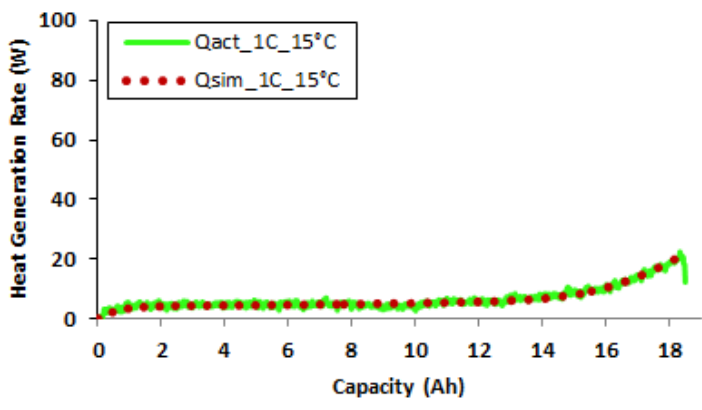

(a) Heat Generation Rate_1C at $15^{\circ} \mathrm{C}$

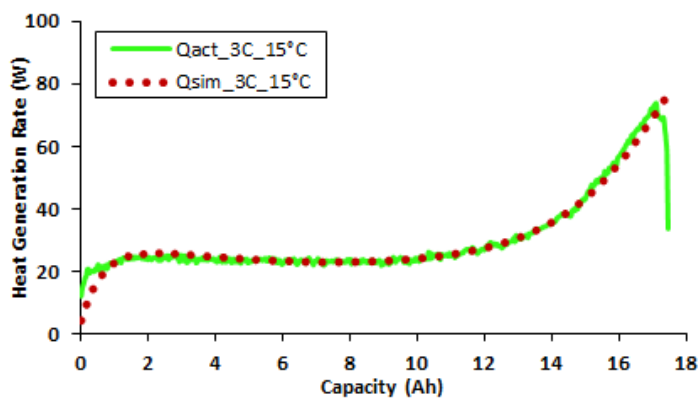

(c) Heat Generation Rate_3C at $15^{\circ} \mathrm{C}$

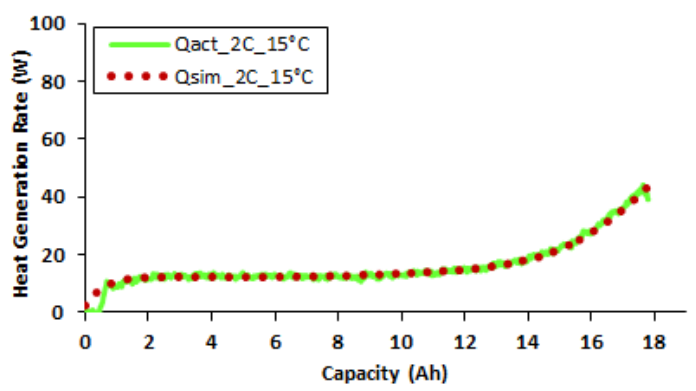

(b) Heat Generation Rate $2 \mathrm{C}$ at $15^{\circ} \mathrm{C}$

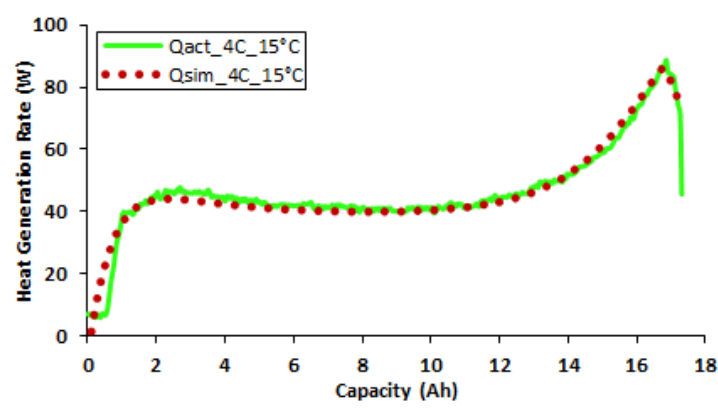

(d) Heat Generation Rate_4C at $15^{\circ} \mathrm{C}$

Figure 9 : Comparison of actual and simulated heat generation rate at $1 \mathrm{C}, 2 \mathrm{C}, 3 \mathrm{C}$ and $4 \mathrm{C}$ at $15{ }^{\circ} \mathrm{C}$ BCs

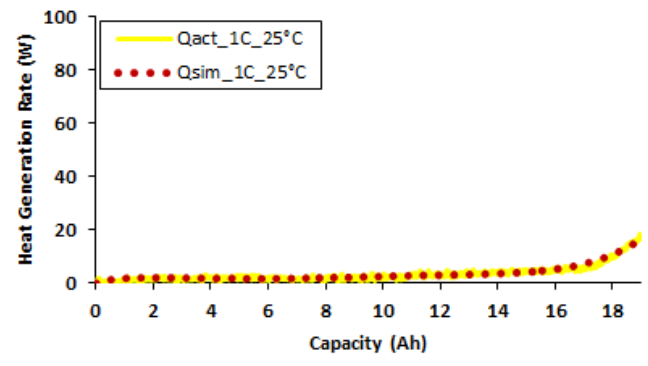

(a) Heat Generation Rate_1C at $25^{\circ} \mathrm{C}$

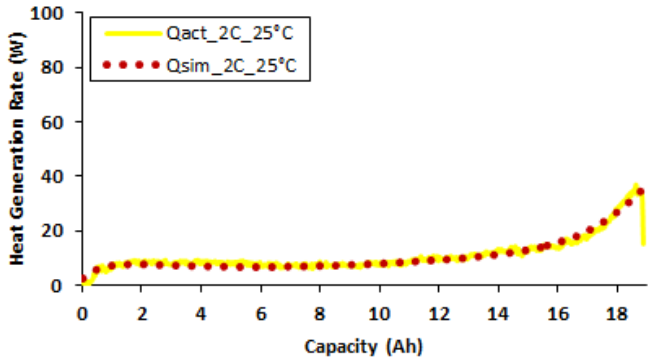

(b) Heat Generation Rate_2C at $25^{\circ} \mathrm{C}$ 


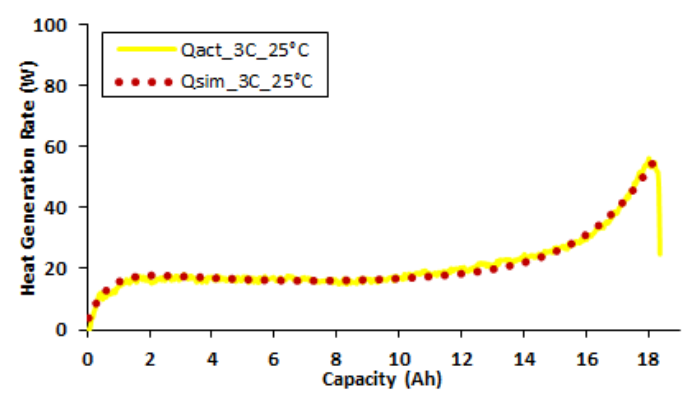

(c) Heat Generation Rate_3C at $25^{\circ} \mathrm{C}$

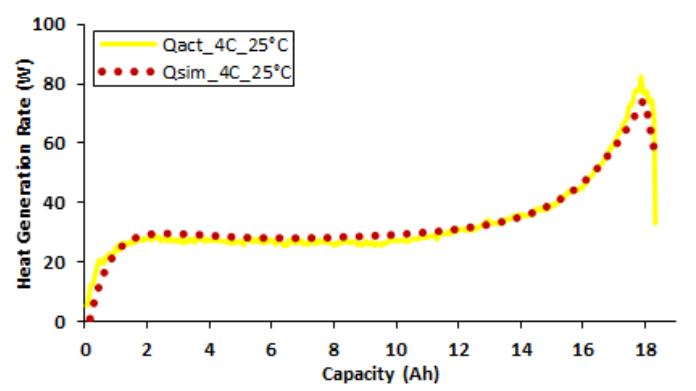

(d) Heat Generation Rate_4C at $25^{\circ} \mathrm{C}$

Figure 10 : Comparison of actual and simulated heat generation rate at $1 \mathrm{C}, 2 \mathrm{C}, 3 \mathrm{C}$ and $4 \mathrm{C}$ at $25^{\circ} \mathrm{C}$ BCs

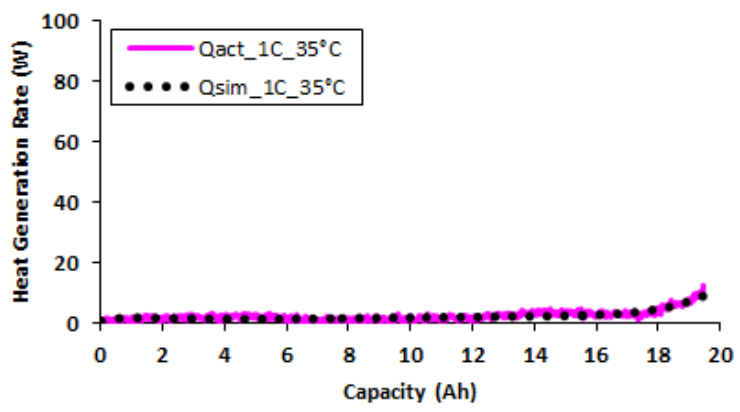

(a) Heat Generation Rate_1C at $35^{\circ} \mathrm{C}$

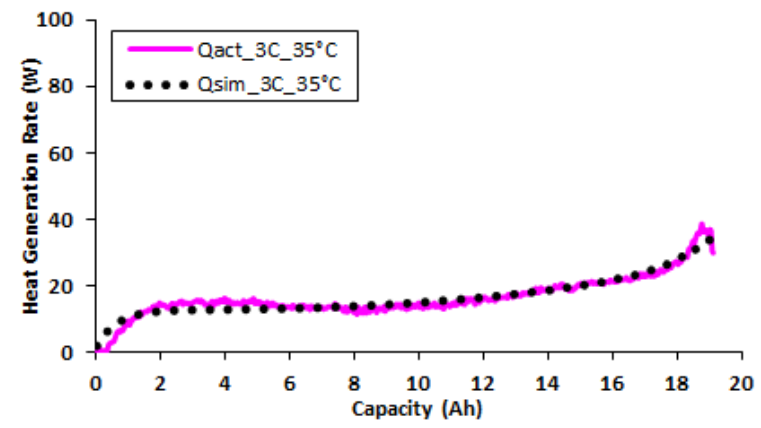

(c) Heat Generation Rate_ $3 \mathrm{C}$ at $35^{\circ} \mathrm{C}$

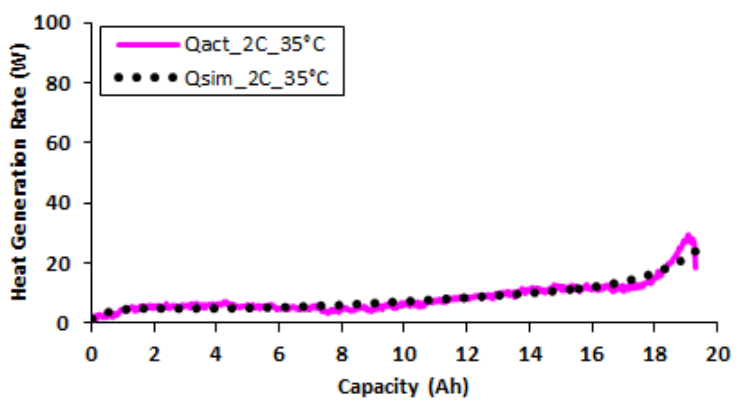

(b) Heat Generation Rate_2C at $35^{\circ} \mathrm{C}$

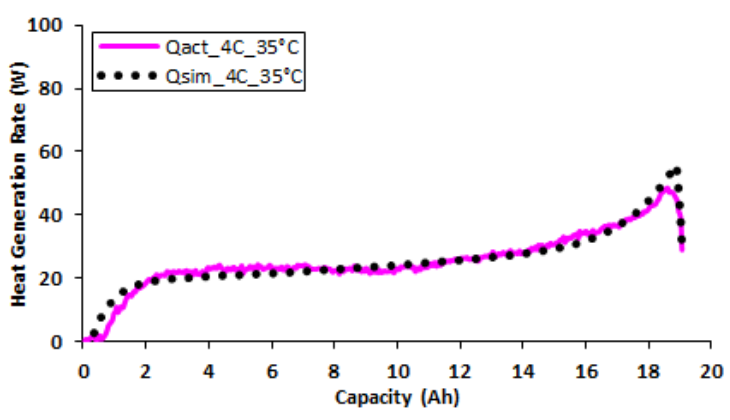

(d) Heat Generation Rate_4C at $35^{\circ} \mathrm{C}$

Figure 11 : Comparison of actual and simulated heat generation rate at $1 \mathrm{C}, 2 \mathrm{C}, 3 \mathrm{C}$ and $4 \mathrm{C}$ at $35^{\circ} \mathrm{C} \mathrm{BCs}$ 